\title{
Growth Profile of Chamaedorea cataractarum (Cascade Palm) Seedlings with Different Colored Plastic Mulch
}

\author{
Ginu George \\ Civil and Environmental Engineering Department, Engineering Center \\ EC3676, 10555 W. Flagler Street, Florida International University, Miami, FL 33174, USA \\ Stewart Reed (Corresponding author) \\ United States Department of Agriculture, ARS, Subtropical Horticulture Research Station \\ 13601 Old Cutler Road, Miami, FL 33158, USA \\ Tel: 786-573-37048Ｅ-mail: Stewart.Reed@ars.usda.gov \\ Berrin Tansel \\ Civil and Environmental Engineering Department, Engineering Center \\ EC3676, 10555 W. Flagler Street, Florida International University, Miami, FL 33174, USA \\ Garry Gordon \\ United States Department of Agriculture, ARS, Subtropical Horticulture Research Station \\ 13601 Old Cutler Road, Miami, FL 33158, USA
}

Received: December 14, 2010 Accepted: January 5, 2011 doi:10.5539/jas.v3n3p39

\begin{abstract}
Cascade palms (Chamaedorea cataractarum Mart.) are slow growing, ornamental plants suitable for both indoor and outdoor use. The purpose of this study was to determine effects of colored plastic mulch on the growth of Chamaedorea cataractarum Mart. Seedlings grown in soil were compared with those grown using red and blue plastic much cover. The study was conducted in triplicate settings at two different green houses and at two different locations in one of the green houses. Plant growth was monitored for plant height, stem thickness at the base, number of leaves and leaflets, chlorophyll a and b, root density, root length and shoot dry weight. Data were analyzed in a randomized complete block design. Light reflected from both mulch colors and the bare substrate had low radiance values in the blue, red and far-red wavelengths. Mulch color had a relatively small significant effect on plant height $(P=0.0728)$. Plants grown on red mulch had smaller height than those grown on bare substrate and on blue mulch. Although the differences were not significant, plants grown on blue mulch had higher growth rates (height, stem diameter), as well as higher number of leaves and leaflets.
\end{abstract}

Keywords: Chamaedorea cataractarum Mart. (Cascade Palm), Colored mulch, Reflected light, Ornamental plants, Photoreceptors, Reflectance, Phytochrome, Chlorophyll, Water conservation

\author{
Abbreviation \\ Cytochrome (CYT) \\ Phototropin (PHOT) \\ Phytochrome (PHY) \\ Phytochrome A (PHYA) \\ Florida International University (FIU) \\ United States Department of Agriculture, Agricultural Research Service (USDA, ARS), Subtropical Horticulture \\ Research Station (SHRS)
}

GFIU, GSHRS and SHRS 
Days after transplanting (DAT)

Average reflectance at $400-500 \mathrm{~nm}$ (blue)

Average reflectance 600-700 nm (red)

Average reflectance 700-800 nm far-red (FR)

\section{Introduction}

\subsection{Growth regulators}

Plant growth is a result of both endogenous and exogenous factors. Plant hormones, auxins, gibberellins, cytokinins and abscisic acid generate the biochemical signals that govern plant growth profile. Light quality has been found to modulate cytokinin and auxin action during in vitro studies. In Spirea nipponica, red light enhanced the effects of Cytokinins as measured in shoot proliferation rate (Norton et al., 1988). Photoreceptors, that translate light quality signals to biomechanical signals, are cytochrome (CYT), phototropin (PHOT) and phytochrome (PHY). CYT and PHOT families are UV-A/blue light receptors while PHY translates red/far-red signals (Banerjee and Batschauer, 2005). Phytochrome A (PHYA) plays a mediating role forming the response of the blue light. CYT1 has been found to be vital in generating the blue high irradiance response while CYT2 is responsible for the blue low irradiance response (Lin, 2000). The phototropin family, namely PHOT1 and PHOT2 helps in auxin transport and determines the plant's sensitivity to auxin (Esmon et al., 2005). Also, the PHY was found to be responsible for internode elongation in M9 apple rootstock grown in vitro (Muleo and Morini, 2008).

\subsection{Plant responses to different light colors}

Modifying the light profile has resulted in different plant responses depending on the plant species used. When chrysanthemum (Dendranthema x grandiflorum), tomato (Lycopersicon esculentum), lettuce (Lactuca sativa) and poinsettia (Euphorbia pulcherrima) were subjected to selectively screened natural light spectrum; it was observed that while chrysanthemum, tomato and lettuce were affected by the modified light profile, poinsettia exhibited no significant effects (Mortensen and Stromme, 1987). In Spirea nipponica explant cultures, the presence of red and far-red light in combination with low concentrations of cytokinin resulted in formation of new shoots and lateral buds (Herrington and McPherson, 1993). In plums (Prunus domestica), blue light caused an increase in the formation of auxiliary buds and a decrease in bud outgrowth while red light encouraged apical dominance resulting in more bud outgrowth (Muleo et al., 2001). Studies on in vitro Pelargonium with incandescent lamps of different wavelength ranges showed that red light encouraged greater stem elongation as compared to white or blue (Appelgren, 1991). In fact, blue light suppressed stem elongation. Light quality affected the leaf size in birch, leaf chlorophyll content and growth in Cymbidium, and stem growth in Pelargonium (Sæbø et al., 1995; Tanaka, et al., 1998; Nhut, et al., 2003). Plant height depends on phytomer formation and growth in length of the internodes. Under in vitro conditions, phytomers developed best under red light, worst under far-red, and blue gave an intermediate response (Muleo and Morini, 2006). When photosensitive films (colorless, red, far-red) were used in growth chambers, it was observed that height response among most of the six plant species used (i.e., Zinnia elegans Jacq., Dendranthema xgrandiflorum Kitam. (chrysanthemum), Cosmos bipinnatus Cav., and Petunia xhybrida Vilm.-Andr.) was discouraged under far-red absorbing film (Cereny et al., 2003). Antirrhinum majus L. (snapdragon) and Rosa xhybrida (miniature rose) were not affected by far-red absorbing film. The far-red absorbing film also delayed anthesis in long day plants by about 13 days.

\subsection{Vegetable crop response to plastic mulch color}

Use of plastic mulch on soil modifies its radiation profile (Decoteau and Friend, 1991). Depending on mulch color, there is a change in the proportion of a particular wavelength range reflected to the underside of leaves. Hence, optical properties of plastic mulch affect the plant's microenvironment and its photobiology. Mulch application also reduces soil water evaporation. Installation of colored mulch has been observed to improve yield in some plants. For example, red mulch resulted in larger and higher number of strawberries (Fragaria ananassa Dutch) as compared to black mulch (Kasperbauer, 2000). Similar results were reported for Basil (Ocimum basilicum L.), where plants grown over red mulch had larger leaf area and greater succulence (Loughrin and Kasperbauer, 2001). When the attributes of aroma were investigated, yellow and green mulch resulted in the highest concentrations of phenolics. Trials conducted with cucumber using four mulch types (transparent polyethylene, silver polyethylene, black polyethylene, paraffin wax coated craft paper) showed that best vegetative growth was under black and the wax coated craft paper (El-Nemr, 2006). Vegetative growth was monitored in terms of plant height, number of leaves, fresh and dry weight of leaves, dry weight of stems, and 
total yield. Many studies have been conducted with colored plastic mulch on vegetable crops but few have been undertaken with ornamental plants, such as palms.

\subsection{Experimental approach}

The purpose of this study was to determine the effects of colored plastic mulch on the growth of Chamaedorea cataractarum Mart. (Cascade Palm). C. cataractarum is also known as Cascade Palm, Cataract Palm or Mexican Hat Palm. Cascade Palm is a rheophyte, with its original habitat being the streambeds of Mexico. Experiments were conducted using red and blue plastic mulch and the results were compared with the plants grown without any mulch cover (i.e., bare substrate). The study was conducted in triplicate settings at three different green houses. Experimental plants were arranged in a randomized complete block design.

\section{Materials and Methods}

\subsection{Experimental design}

The study was conducted in the greenhouses located at Florida International University (FIU) and the United States Department of Agriculture, Agricultural Research Service (USDA, ARS), Subtropical Horticulture Research Station (SHRS) in Miami, Florida. Protocols at the FIU and SHRS sites were similar except as noted below. Palms, supplied Redland Nursery (Homestead, Florida), were separated into groups of similar size and plants in each size range were distributed equally among the treatments. At FIU, the study consisted of 21 Cascade palms, which were distributed among 3 treatments: red plastic mulch, blue plastic mulch and a no mulch (control) group. The study at the SHRS had two groups of 12 replicates in each of the aforementioned treatments. The mulch used was embossed colors, 1 Mil, plastic mulch (Robert Marvel Plastic Mulch LLC, Annville, PA). Palms were transplanted into 6-inch pots on 26 and 27 August 2008. One teaspoon (5 g) of 8-4-12 Improved Palm Special \#6878 fertilizer (Atlantic Fertilizer \& Chemical Company, Homestead, FL) was placed $1.3 \mathrm{~cm}$ below the root at time of transplanting. The potting substrate consisted of $10 \%$ sand, $10 \%$ perlite, $40 \%$ peat and $40 \%$ compost mix (Atlantic Fertilizer \& Chemical Company, Homestead, FL). The potting substrate was covered completely with colored plastic mulch. To isolate individual palms from effects of any background colors, the 6-inch pots were placed into larger 10-inch pots, with mulch of the same color lining the inner surface of the larger pot as illustrated in Figure 1. Inner pot height was periodically adjusted so that $60-70 \%$ of leaf area was below the outer pot's surface. Palms were grown under $20 \%$ neutral shade cloth that did not affect the spectrum of light reaching each pot. Each palm was watered manually once every two days with an average of $700 \mathrm{~mL}$ water which was enough to completely saturate the potting medium with approximately $14 \%$ leaching. Excess water was allowed to freely drain through the opening below the pot. Nineteen days after transplanting (DAT) plants were sprayed with a fungicide (Bravo) to control fungal leaf spots. Pots were randomly rearranged every two weeks to even out differences brought about by variations in the greenhouse.

\section{Insert Figure 1}

To test the effects of plastic mulch color on C. cataractarum, pots were arranged in a random pattern. There were two plastic mulch treatments, red and blue, and a bare potting substrate control with seven replications of each treatment at FIU and 12 replications at each SHRS site.

\subsection{Data collections}

Attributes measured included plant height, thickness at the base of the stem, number of leaves and leaflets, ratio of chlorophyll a to chlorophyll $b$, root density, root length and shoot dry weight. Plant height measured from the base of the stem to the base of the newest leaf, stem diameter measured $1.27 \mathrm{~cm}$ above the soil surface, and leaf and leaflet numbers were determined weekly from 18 September to 4 December 2008. All unfolded green leaves were included in the leaf count. Dead leaves were excluded from the count. A new leaflet was counted once the tips were no longer in contact.

\subsection{Root analysis}

Plants grown at the FIU greenhouse were used for destructive sampling. Whole plants were removed from the pots 162 DAT. Pot were immerged in water and gentle agitation applied to free roots from the potting media. Roots were carefully washed free from any remaining material and blotted dry on a paper towel. Root and shoot tissues were separated and a fresh weight determined for each. The number of root branches was counted and the branches separated for scanning. Roots were scanned on a commercial scanner. Root length, diameter and density per pot volume were determined using Delta-T Scan software (Delta-T-Devices LTD., Cambridge, U.K.). Root and shoot tissue were dried in a gravity convection oven at $65^{\circ} \mathrm{C}$ until a constant weight was achieved and then a dry weight recorded. 


\subsection{Chlorophyll analysis}

At 162 days after transplantation (DAT) chlorophyll fluorescence was determined with an OS-30p chlorophyll fluorometer (Opti-Science, Hudson, NH, U.S.A.) and chlorophyll content with a Minolta Chlorophyll Meter, SPAD-502 (Spectrum Technologies Inc., Plainfield, Il, U.S.A.). Three SPAD readings were recorded on each leaflet. Chlorophyll $\mathrm{a}$ and $\mathrm{b}$ were determined from leaf tissue according to the method described by Edelenbos et al., 2001. A young, fully emerged leaf was selected (i.e., one that had spent its entire existence under the influence of light reflected from the colored mulch). The leaf blade was cut off at the top of the petiole and its weight was recorded. Plant tissue was homogenized in acetone. The suspension was stirred for $1 \mathrm{~h}$ with gyratory shaker, centrifuged for 10 minutes at $3000 \mathrm{rpm}$ and the supernatant was saved. The pellet was re-extracted three more times and the supernatant was pooled and stored at $4{ }^{\circ} \mathrm{C}$ in the dark for HPLC analysis. A Dionex DX 500 HPLC system equipped with an AD-20 UV-Vis detector operating at $440 \mathrm{~nm}$ was used for analysis (Dionex, Sunnyvale, CA, U.S.A.). Separations were performed on an Agilent Zorbax ODS column ( $5 \mu \mathrm{m} ; 250$ x $4.6 \mathrm{~mm}$ i.d.) protected with an Agilent Zorbax ODS guard cartridge $(5 \mu \mathrm{m}$; 12.5 x $4.6 \mathrm{~mm}$ i.d.; Agilent Technologies, Santa Clara, CA, U.S.A.). The column temperature was maintained at $30{ }^{\circ} \mathrm{C}$ and the mobile phases consisted of

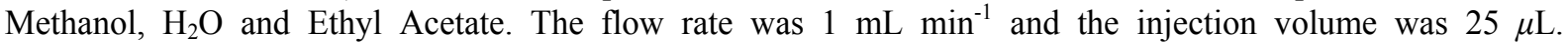
Chlorophyll standards were acquired from Sigma Aldrich (Chlorophyll a C5753-1MG, Chlorophyll b C5878-1MG; Sigma-Aldrich, St. Louis, MO, U.S.A.). Retention times for Chlorophyll a and b were determined to be 26.5 and 20.5 minutes, respectively.

\subsection{Spectral reflectance}

Spectral reflectance from colored plastic mulch was measured with a FieldSpec ${ }^{\circledR}$ Hand Held Spectroradiometer (Analytical Spectral Devices, Inc., Boulder, CO, U.S.A.). Measurements were taken indoors with background lighting provided by a 14.5 volt, 50 Watt lamp. Readings lasting $270 \mathrm{msec}$ were recorded for wavelengths between $325-1075 \mathrm{~nm}$ at $1 \mathrm{~nm}$ intervals. The reported value represents a mean of 170 readings taken at each wavelength.

Statistical analysis was conducted using SAS 8 software (SAS Inst. 1999). Treatments were organized in a randomized complete block design with each location, FIU and two SHRS sites considered as blocks. Treatment effects were determined using the mixed model procedure of SAS. Mulch color was a fixed effect and location being random. Means separation was accomplished using Tukey's test at $\alpha<0.05$. Differences were identified as slightly significant at $P \leq 0.10$ and as significant at $P \leq 0.05$. Probability levels are noted in parentheses when $P>$ 0.05 .

\section{Results}

\subsection{Spectral reflectance of different colored plastic mulch}

The reflectance of light from $350 \mathrm{~nm}$ to $850 \mathrm{~nm}$ by the colored plastic mulches and bare substrate is given in Figure 2. Bare substrate had an average reflectance at 400-500 nm (blue), 600-700 nm (red) and 700-800 nm for far-red (FR) of $0.032 \%, 0.081 \%$ and $0.155 \%$, respectively. Peak reflectance for both the blue and red mulch was at the high end of the wavelength range for that particular color. At the phytochrome action peaks of $660 \mathrm{~nm}$ for red and $730 \mathrm{~nm}$ for FR, reflectance from bare substrate was $0.084 \%$ and $0.134 \%$, respectively. The blue plastic mulch had a reflectance peak of $1.67 \%$ at $472 \mathrm{~nm}$. At $660 \mathrm{~nm}$ and $730 \mathrm{~nm}$, blue mulch reflectance was 0.201 and 0.242 , respectively. In the red region there was an average reflectance of $0.173 \%$ with peak reflectance at 668 $\mathrm{nm}$. Red plastic mulch had a peak reflectance in the red region of $1.957 \%$ at $700 \mathrm{~nm}$ and in the blue region had a peak at $400 \mathrm{~nm}$ with an average reflectance of $0.153 \%$. The phytochrome action peaks of $660 \mathrm{~nm}$ and $730 \mathrm{~nm}$ had reflectance values of $1.625 \%$ and $2.203 \%$, respectively. The reflectance ratios for Blue:Red and Red:FR for the surfaces corresponding to bare substrate as well as blue and red plastic much are presented in Table 1. Table 2 presents the radiance profile of surfaces at different wavelengths.

Insert Figure 2

Insert Table 1

Insert Table 2

\subsection{Effect of mulch color on palm physical characteristics}

Table 3 presents the analysis of variance results. Mulch color had no significant effect on the increase in stem diameter, leaf number, or number of leaflets for aboveground part of plants. Stem dry weight, root size and leaf chlorophyll content were determined from plants grown at the GFIU site only. Root dry weight, length and stem diameter did not significantly differ with mulch color. Chlorophyll a, b and the a:b ratio also did not differ 
significantly with mulch color. Mulch color had a slightly significant effect on palm plant height $(P=0.0728)$. Plants grown on red mulch had significantly smaller plant height than those grown on bare substrate and had a slightly significant lower height than plants grown on blue mulch as presented in Table 4 . Although there were no significant differences, blue mulch consistently produced higher height, stem diameters, number of leaves and number of leaflets than plants grown on red.

Insert Figure 3

\subsection{Leaf area}

Leaf area for two randomly selected plants from each treatment at the FIU site was measured on Day 94 and again on Day 134. These measurements showed plants added 1, 2 and 3 new leaves with a total leaf area of 16.8, 18.5 and $11.5 \mathrm{~cm}^{2}$ for the blue mulch, bare substrate and red mulch; respectively. Red mulch produced more new leaves than other treatments; however, the blue mulch treatments added a higher total leaf area than red.

\subsection{Chlorophyll}

There were no differences between the mulch treatments in terms of chlorophyll $a$, chlorophyll $b$ and $a / b$ ratio as presented in Table 5. However, the red mulch treatment resulted in a $1.4 \mathrm{x}$ higher chlorophyll a and $1.3 \mathrm{x}$ higher chlorophyll $\mathrm{b}$ content than that produced on blue mulch. This higher concentration of chlorophyll with the red mulch may in part be the result of lower dry weights of plants grown on red mulch.

Insert Table 3

Insert Table 4

Insert Table 5

\subsection{Palm growth rate}

Figure 3 presents the regression equations for weekly measurements of plant height and mulch color taken at each of the three locations. At the GFIU and GSHRS sites the slope of the regression lines show plants grown on blue plastic mulch had the highest weekly growth rate. Palm plants on blue mulch grew at an average of 0.119 $\mathrm{cm} \mathrm{wk}^{-1}$ at GFIU, almost double the rate for red mulch $\left(0.062 \mathrm{~cm} \mathrm{wk}^{-1}\right)$ and $1.4 \mathrm{x}$ that of plants grown on bare substrate $\left(0.084 \mathrm{~cm} \mathrm{wk}^{-1}\right)$. At the GSHRS site the growth rate for blue plastic mulch $\left(0.098 \mathrm{~cm} \mathrm{wk}^{-1}\right)$ was $1.2 \mathrm{x}$ faster than that on red plastic $\left(0.056 \mathrm{~cm} \mathrm{wk}^{-1}\right)$ mulch or bare substrate $\left(0.054 \mathrm{~cm} \mathrm{wk}^{-1}\right)$. Blue mulch produced the lowest growth rate at the SHRS site after 23 weeks. Up until week 19, plants grown on blue mulch exhibited the highest growth rate; from week 19 to week 23 plants on both bare substrate and red mulch enjoyed a rapid growth that was not present with blue plastic mulch at the SHRS site. This resulted in the higher overall growth rate for bare substrate and red over blue mulch. Stem diameter shows a growth pattern similar to plant height in that blue plastic mulch produced the largest stem diameters as shown in Figure 4. Blue plastic mulch produced an increase in diameter of $0.140,0.080$ and $0.064 \mathrm{~cm} \mathrm{wk}^{-1}$, red mulch $0.127,0.057$ and $0.054 \mathrm{~cm} \mathrm{wk}^{-1}$ and bare substrate $0.099,0.061$ and $0.064 \mathrm{~cm} \mathrm{wk}^{-1}$ for the GFIU, GSHRS and SHRS sites, respectively.

Tables 6 and 7 present the observed changes in height and stem diameter of the palms grown on different mulches which were placed at different green house locations, respectively. The comparison of the magnitudes of the slopes in the linear models indicate that blue mulch had higher rates of change in palm height over time at all three locations in comparison to those grown on bare substrate and red mulch (Table 6). For the stem diameter, palms grown on blue mulch had higher rates of increase at two locations (GSRS and GFIU) than the others. At the SHRS location, palms grown on blue mulch had similar rates of increase with those grown on bare substrate.

\section{Insert Table 6}

Insert Table 7

\section{Discussion}

Mulch color did not have a significant effect on stem diameter, leaf and leaflet number, root dry weight, root length and root diameter. However, plants grown on red mulch had significantly smaller plant height than those grown on bare substrate and blue mulch. Csizinszky et al. (1995) observed inconsistent differences in tomato plant growth and yields with blue and red mulch colors. Gordon et al. (2008 and 2010) observed no significant differences between blue and red plastic mulch for plant height and fruit yield in squash (2008) and okra (2010). Blue light is known to inhibit apical dominance in plants (Cosgrove, 1981; Mortensen and Stromme, 1987; Appelgren, 1991; Oyaerta et al., 1999; Runkle, and Heins, 2001; Muleo and Morini, 2008); however, a complex interaction of light induced effects regulates the response. The ratio of FR:R light can effect growth. 
Kasperbauer (1987) found plants exposed to far-red light at the end of each day developed longer internodes and fewer branches. Dry matter partitioning also, was related to far-red:red light ratio. Fernbach and Mohr (1990) reported that the red light effect on phytochrome controlled growth inhibition in Scots pine (Pinus sylvestris L.) seedlings, however, the seedling required blue or ultraviolet light to become fully responsive. Far-red light removed the inhibition on elongation. Rapparini et al. (1999) also observed shoot growth inhibition when blue light was associated with a high rate of cycling between red and far-red forms of phytochrome. In contrast, Macedo et al. (2010) observed that plants grown under blue light induced a greater number of leaves per plant, and larger leafblade area than those grown under red or green light. Schuerger et al. (1997) reported that pepper plants grown under red LED's supplemented with blue light produced thicker leaves than those grown under red alone or red supplemented with far-red LED's.

The results indicate that there was no growth inhibition induced by blue light reflected from the mulch. Light reflected from both mulch colors and the bare substrate had low radiance values in the blue, red and FR wavelengths. The R:FR ratio for all treatments was close to that reported by Appelgren (1991) for incandescent light (0.72) where stem elongation was not inhibited. The B:R ratio in this study, also, was significantly lower than the B:R ratio which resulted in the blue light response observed by Applegren (1991). Cascade palms are slow growing shade adapted plants. The observed effects of the plastic mulch on palm growth and development were relatively small; however, the response tended favor a blue light stimulated increase in leaf number and plant height.

\section{References}

Appelgren, M. (1991). Effects of light quality on stem elongation of Pelargonium in vitro. Scientia Hortic, 45:345-351. doi:10.1016/0304-4238(91)90081-9, http://dx.doi.org/10.1016/0304-4238(91)90081-9

Banerjee, R \&. Batschauer, A. (2005). Plant blue-light receptors. Planta, 220:498-502. doi:10.1007/s00425-004-1418-z, http://dx.doi.org/10.1007/s00425-004-1418-z

Cereny, T.A., Faust, J.E., Layne, D.R., \& Rajapakse, N.C. (2003). Influence of photoselective films and growing season on stem growth and flowering on six plant species. Am. Soc. Hort. Sci., 4:486-491.

Cosgrove, D.J. (1981). Rapid suppression of growth by blue light occurrence, time course, and general characteristics. Plant Physiol., 67:584-590. doi:10.1104/pp.67.3.584, http://dx.doi.org/10.1104/pp.67.3.584

Csizinszky, A.A., Schuster, D.J., \& Kring, J.B. (1995). Color mulches influence yield and insect pest populations in tomatoes. J. Amer. Soc. Hort. Sci., 120(5):778-784.

Decoteau, D.R. \& Friend, H.H. (1991). Plant responses to wavelength selective mulches and row covers: a discussion of light quality effects plants. Proc. Natl. Agric. Plastics Congr. (USA), 23:46-51.

Edelenbos, M., Christensen, L.P., \& Grevsen, K. (2001). HPLC determination of chlorophyll and carotenoid pigments in processed green pea cultivars (Pisum sativum L.). J. Agric. Food Chem., 49:4768-4774. doi:10.1021/jf010569z, http://dx.doi.org/10.1021/jf010569z

El-Nemr, A. Maged. (2006). Effect of mulch types on soil environmental conditions and their effect on the growth and yield of cucumber plants. J. App. Sci. Res., 2:67-73.

Esmon, C.A., Pedmale, U.V., \& Liscum, E. (2005). Plant tropisms: providing the power of movement to a sessile organism. Int. J. Dev. Biol., 49:665-74. doi:10.1387/ijdb.052028ce, http://dx.doi.org/10.1387/ijdb.052028ce

Fernbach, E. \& Mohr, H. (1990). Coaction of blue/ultraviolet-A light and light absorbed by phytochrome in controlling growth of pine (Pinus sylvestris L.) seedlings. Planta, 180:212-216. doi:10.1007/BF00193998, http://dx.doi.org/10.1007/BF00193998

Gordon, G.G., Foshee, W.G., Reed, S.T., Brown, J.E., Vinson, E., \& Woods, F.M. (2008). Plastic mulches and row covers on growth and production of summer squash. Internatl. J. Veg. Sci., 14(4):322-338. doi:10.1080/19315260802215830, http://dx.doi.org/10.1080/19315260802215830

Gordon, G.G., Foshee, W.G., Reed, S.T., Brown, J.E., \& Vinson, E. (2010). The effects of colored plastic mulches and row covers on the growth and yield of okra. HortTechnology, 20(1):224-233.

Herrington, E. \& McPherson, J.C. (1993). Light quality growth promotion of Spirea nipponica: the influence of a low photon fluence rate and transfer time to a higher fluence rate. Plant Cell Tiss. Org. Cult., 32:161-167. doi:10.1007/BF00029838, http://dx.doi.org/10.1007/BF00029838 
Kasperbauer, M.J. (1987). Far-red light reflection from green leaves and effects on phytochrome-mediated assimilate partitioning under field conditions. Plant Physiol., 85:350-354. doi:10.1104/pp.85.2.350, http://dx.doi.org/10.1104/pp.85.2.350

Kasperbauer, M.J. (2000). Strawberry yield over red versus black plastic mulch. Crop Sci., 40:171-174. doi:10.2135/cropsci2000.401171x, http://dx.doi.org/10.2135/cropsci2000.401171x

Lin, C. (2000). Plant blue-light receptors. Trends Plant Sci. 5:337-42. doi:10.1016/S1360-1385(00)01687-3, $\mathrm{http} / / / \mathrm{dx}$. doi.org/10.1016/S1360-1385(00)01687-3

Loughrin, J.H. \& Kasperbauer, M.J. (2001). Light reflected from colored mulches affects aroma and phenol content of sweet basil (Ocimum basilicum L.) leaves. J. Agric. Food Chem., 49:1331-1335. doi:10.1021/jf0012648, http://dx.doi.org/10.1021/jf0012648

Macedo, A.F., Leal-Costab, M.V., Tavaresb, E.S., Lagec, C.L., \& Esquibe, M.A. (2010). The effect of light quality on leaf production and development of in vitro-cultured plants of Alternanthera brasiliana Kuntze. Environ. Exp. Bot. available doi:10.1016/j.envexpbot.2010.05.012.

Mortensen, L.M. \& Stromme, E. (1987). Effects of light quality on some greenhouse crops. Sci. Horti., 33:27-36. doi:10.1016/0304-4238(87)90029-X, http://dx.doi.org/10.1016/0304-4238(87)90029-X

Muleo, R. \& Morini, S. (2006). Light quality regulates shoot cluster growth and development of MM106 apple genotype in vitro culture. Sci. Hortic., 108:364-70. doi:10.1016/j.scienta.2006.02.014, http://dx.doi.org/10.1016/j.scienta.2006.02.014

Muleo, R. \& Morini, S. (2008). Physiological dissection of blue and red light regulation of apical dominance and branching in M9 apple rootstock growing in vitro. J. Plant. Physiol., 165:1838-846. doi:10.1016/j.jplph.2008.01.007, http://dx.doi.org/10.1016/j.jplph.2008.01.007

Muleo, R., Morini, S., \& Casano, S. (2001). Photoregulation of growth and branching of plum shoots: physiological action of two photosystems. In Vitro Cell. Dev. Biol. Plant, 37:609-617. doi:10.1007/s11627-001-0107-x, http://dx.doi.org/10.1007/s11627-001-0107-x

Norton, R.C., Norton, E.M., \& Herrington, T. (1988). Light quality and light pipe in the micropropagation of woody ornamental plants grown in vitro. Acta Hort., 227:453-456.

Nhut, DT, Takamura, T., Watanabe, H., Okamoto, K., \& Tanaka, M. (2003). Responses of strawberry plantlets cultured in vitro - under super bright red and blue light-emitting diodes (LEDs). Plant Cell Tiss. Org. Cult., 73:43-52. doi:10.1023/A:1022638508007, http://dx.doi.org/10.1023/A:1022638508007

Oyaerta, E., Volckaertb, E., \& Debergh, P.C. (1999). Growth of chrysanthemum under coloured plastic films with different light qualities and quantities. Sci. Hortic., 79:195-205. doi:10.1016/S0304-4238(98)00207-6, http://dx.doi.org/10.1016/S0304-4238(98)00207-6

Rapparini, F., Rotondi, A., \& Baraldi, R. (1999). Blue light regulation of the growth of Prunus persica plants in a long term experiment: morphological and histological observations. Trees, 14:169-176. doi:10.1007/PL00009760, http://dx.doi.org/10.1007/PL00009760

Runkle, E.S. \& Heins, R.D. (2001). Specific functions of red, far red, and blue light in flowering and stem extension of long-day plants. J. Amer. Soc. Hort. Sci., 126(3):275-282.

Sæbø, A., Krekling, T., \& Appelgren, M. (1995). Light quality affects photosynthesis and leaf anatomy of birch plantlets in vitro. Plant Cell Tiss. Org. Cult., 51:187-93.

Schuerger, A.C., C.S. Brown, and E.C. Stryjewski. 1997. Anatomical features of pepper plants (Capsicum annuит 1.) grown under red light-emitting diodes supplemented with blue or far-red light. Annals of Botany 79:273-282. doi:10.1006/anbo.1996.0341, http://dx.doi.org/10.1006/anbo.1996.0341

Tanaka M, Takamura, T., Watanabe, H., Endo, M., Yanagi, T., \& Okomoto, K. (1998). In vitro growth of Cymbidium plantlets cultured under super bright red and blue light-emitting diodes (LEDs). J. Hortic. Sci. Biotechnol., 73:39-44. 
Table 1. Blue:Red and Red:Far-Red reflectance ratios from mulch surfaces.

\begin{tabular}{|l|c|c|}
\hline Mulch & $\begin{array}{c}\text { Blue:Red } \\
(400-500: 600-700 \mathrm{~nm})\end{array}$ & $\begin{array}{c}\text { Red:Far-Red } \\
(600-700: 700-800 \mathrm{~nm})\end{array}$ \\
\hline Bare substrate & 0.399 & 0.524 \\
\hline Blue & 6.512 & 0.367 \\
\hline Red & 0.105 & 0.687 \\
\hline
\end{tabular}

Table 2. Total radiance from mulch surfaces at different wavelength regions.

\begin{tabular}{|l|c|c|c|}
\hline \multirow{2}{*}{ Mulch } & \multicolumn{3}{|c|}{$\begin{array}{c}\text { Total radiance } \\
\left(\mathrm{W} \cdot \mathrm{m}^{-1} \cdot \mathrm{sr}^{-1} \cdot \mathrm{nm}^{-1}\right)\end{array}$} \\
\cline { 2 - 4 } & $\begin{array}{c}\text { Blue Region } \\
(400-500 \mathrm{~nm})\end{array}$ & $\begin{array}{c}\text { Red Region } \\
(600-700 \mathrm{~nm})\end{array}$ & $\begin{array}{c}\text { Far-Red Region } \\
(700-800 \mathrm{~nm})\end{array}$ \\
\hline Bare substrate & 0.000 & 0.008 & 0.100 \\
\hline Blue & 0.158 & 0.000 & 0.137 \\
\hline Red & 0.015 & 0.227 & 0.348 \\
\hline
\end{tabular}

Table 3. Mixed model type 3 test results for effects of mulch on differences in plant height, stem diameter, number of leaves and number of leaflets of palm plants grown for 19 weeks on bare substrate or blue or red plastic mulch at GFIU.

\begin{tabular}{|l|c|c|c|}
\hline Variable & Numerator DF & Denominator DF & $P>\mathrm{F}$ \\
\hline Plant height & 2 & 71 & 0.0728 \\
\hline Stem diameter & 2 & 71 & 0.3644 \\
\hline Number of leaves & 2 & 71 & 0.3939 \\
\hline Number of leaflets & 2 & 71 & 0.3439 \\
\hline Root dry weight & 2 & 12 & 0.9551 \\
\hline Stem dry weight & 2 & 12 & 0.4760 \\
\hline Root diameter & 2 & 12 & 0.3328 \\
\hline Root length & 2 & 12 & 0.8449 \\
\hline Chlorophyll a & 2 & 12 & 0.3563 \\
\hline Chlorophyll b & 2 & 12 & 0.5319 \\
\hline Chlorophyll a/b & 2 & 12 & 0.9856 \\
\hline
\end{tabular}

Table 4. Least square means estimate and Tukey mean separation for differences in plant height, stem diameter, number of leaves and number of leaflets for 19 weeks of growth on bare substrate or blue or red plastic mulch

\begin{tabular}{|l|c|c|c|c|c|}
\hline Mulch & $\begin{array}{c}\text { Plant height } \\
(\mathrm{cm})\end{array}$ & Stem diameter $(\mathrm{mm})$ & Number of leaves & Number of leaflets & $\begin{array}{c}\text { Stem dry weight } \\
(\mathrm{g})\end{array}$ \\
\hline Bare & $1.82^{\mathrm{a}}$ & 2.34 & 0.64 & 5.47 & 0.61 \\
\hline Blue & $1.73^{\mathrm{b}}$ & 2.46 & 0.85 & 6.26 & 0.72 \\
\hline Red & 1.24 & 2.18 & 0.68 & 6.09 & 0.63 \\
\hline
\end{tabular}

${ }^{a}$ not significantly different from red at $P>0.05$.

${ }^{\mathrm{b}}$ significantly different from red at $P>0.0741$.

Table 5. Least square means estimate and Tukey mean separation for chlorophyll a, chlorophyll $b$ and the chlorophyll a/b ratio $\left(\mu \mathrm{g} \mathrm{g}^{-1}\right)$.

\begin{tabular}{|l|c|c|c|}
\hline Mulch & $\begin{array}{c}\text { Chlorophyll a } \\
\left(\mu \mathrm{g} \mathrm{g}^{-1}\right)\end{array}$ & $\begin{array}{c}\text { Chlorophyll b } \\
\left(\mu \mathrm{g} \mathrm{g}^{-1}\right)\end{array}$ & Chlorophyll a/b \\
\hline Bare substrate & $4.79^{\mathrm{a}}$ & $1.34^{\mathrm{a}}$ & $0.270^{\mathrm{a}}$ \\
\hline Blue & $5.47^{\mathrm{a}}$ & $1.57^{\mathrm{a}}$ & $0.267^{\mathrm{a}}$ \\
\hline Red & $7.59^{\mathrm{a}}$ & $2.08^{\mathrm{a}}$ & $0.266^{\mathrm{a}}$ \\
\hline
\end{tabular}

${ }^{a}$ not significantly different at $P>0.05$ 
Table 6. Height profile of seedlings grown at different locations growth on bare substrate or blue or red plastic mulch.

y: palm height $(\mathrm{cm})$

\begin{tabular}{|l|c|c|c|}
\hline \multirow{2}{*}{ Location } & \multicolumn{3}{|c|}{ Palm height $(\mathrm{cm})$} \\
\cline { 2 - 4 } & Bare substrate & Blue mulch & Red mulch \\
\hline SHRS & $\mathrm{y}=0.0448 \mathrm{x}+0.8062$ & $\mathrm{y}=0.156 \mathrm{x}+1.7764$ & $\mathrm{y}=0.0278 \mathrm{x}+1.6102$ \\
\hline GSRS & $\mathrm{y}=0.0541 \mathrm{x}+3.0949$ & $\mathrm{y}=0.068 \mathrm{x}+2.4533$ & $\mathrm{y}=0.0564 \mathrm{x}+2.8758$ \\
\hline GFIU & $\mathrm{y}=0.0846 \mathrm{x}+6.4651$ & $\mathrm{y}=0.119 \mathrm{x}+5.7792$ & $\mathrm{y}=0.0629 \mathrm{x}+4.6962$ \\
\hline
\end{tabular}

$\mathrm{x}$ : time after transplanting (weeks)

Table 7. Stem diameter profile of seedlings grown at different locations growth on bare substrate or blue or red plastic mulch.

\begin{tabular}{|l|c|c|c|}
\hline \multirow{2}{*}{ Location } & \multicolumn{3}{|c|}{ Stem diameter $(\mathrm{mm})$} \\
\cline { 2 - 4 } & Bare substrate & Blue mulch & Red mulch \\
\hline SHRS & $\mathrm{y}=0.0648 \mathrm{x}+1.9902$ & $\mathrm{y}=0.0643 \mathrm{x}+2.1566$ & $\mathrm{y}=0.0549 \mathrm{x}+2.4575$ \\
\hline GSRS & $\mathrm{y}=0.0611 \mathrm{x}+2.9100$ & $\mathrm{y}=0.0801 \mathrm{x}+2.6175$ & $\mathrm{y}=0.0575 \mathrm{x}+2.7274$ \\
\hline GFIU & $\mathrm{y}=0.0994 \mathrm{x}+4.5306$ & $\mathrm{y}=0.1406 \mathrm{x}+4.2570$ & $\mathrm{y}=0.1275 \mathrm{x}+3.6995$ \\
\hline
\end{tabular}

y: stem diameter $(\mathrm{mm})$

$\mathrm{x}$ : weeks after transplanting

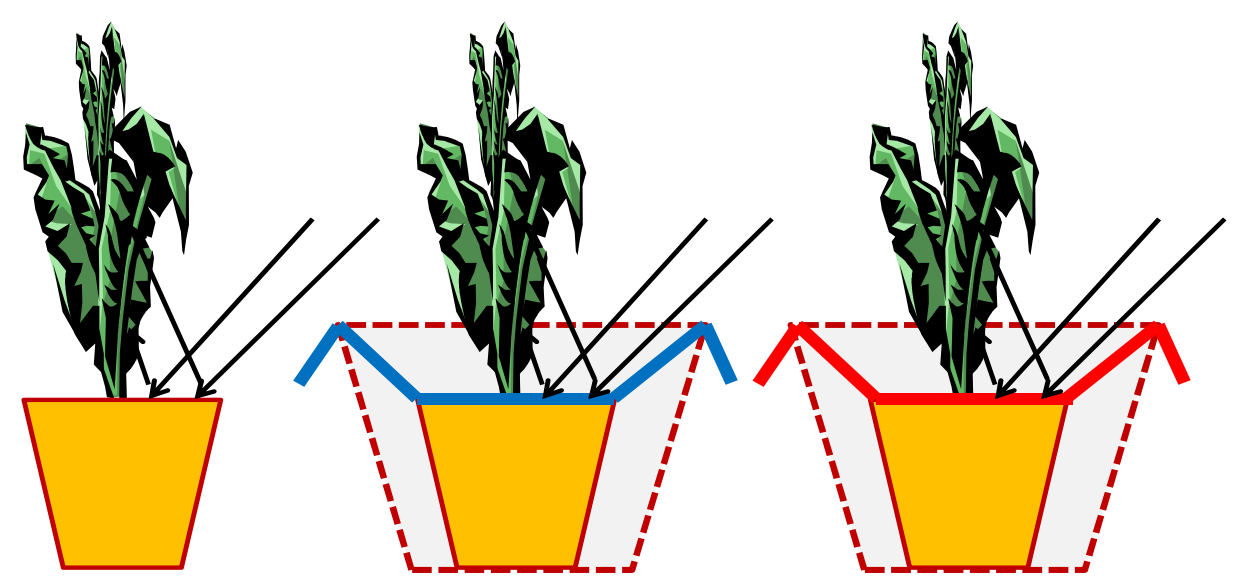

(a)

(b)

(c)

Figure 1. Placement of plastic mulch and seedlings for green house studies: (a) bare substrate, (b) blue plastic mulch, (c) red plastic mulch.

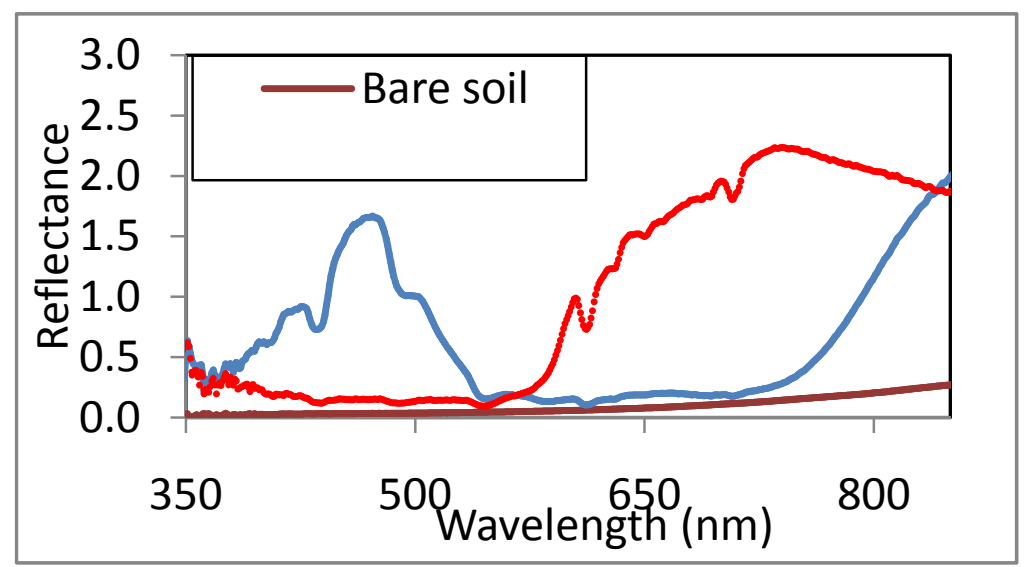

Figure 2. Reflectance spectra of bare substrate, blue mulch and red mulch 

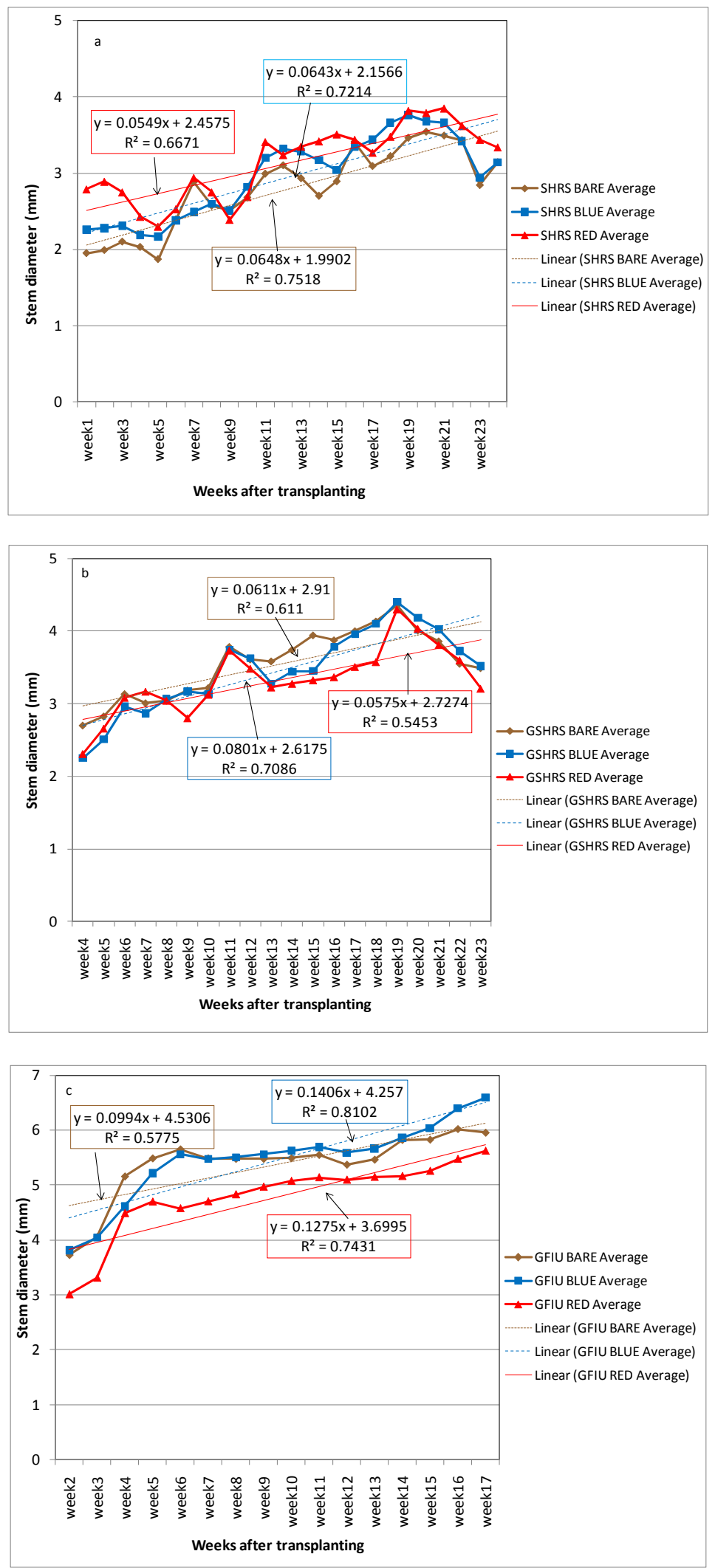

Figure 3. Effect of colored mulch on stem diameter of the plants grown at different test locations 

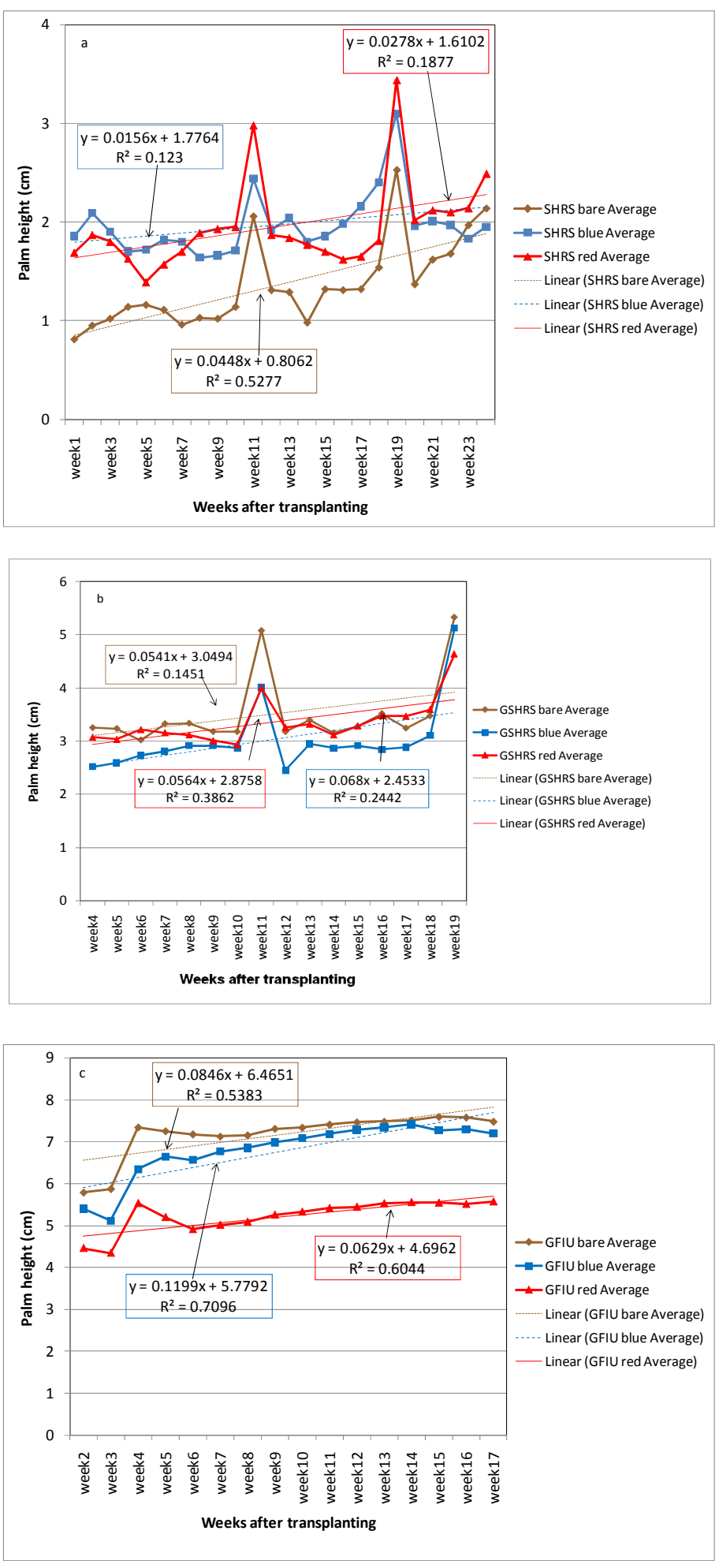

Figure 4. Effect of colored mulch on height of plants grown at different test locations 